\title{
Phytochemical Compounds and Pharmacological Activities of Vitis vinifera L.: An Updated Review
}

\author{
Muhamad Insanu 1(D), Hana Karimah ${ }^{1}$ (D), Hegar Pramastya ${ }^{1}$ (D), Irda Fidrianny 1 (i) \\ 1 Department of Pharmaceutical Biology, School of Pharmacy, Bandung Institute of Technology, Bandung, Indonesia; \\ muhamad.insanu@gmail.com (M.I.); \\ * Correspondence: muhamad.insanu@gmail.com (M.I.);
}

Scopus Author ID 55479820400

Received: 17.01.2021; Revised: 17.02.2021; Accepted: 22.02.2021; Published: 1.03.2021

\begin{abstract}
Grapes (Vitis vinifera L.) are commonly known grape species that belong to the Vitis genus in the Vitaceae family and come from western Asia and southern Europe. This review consists of traditional uses, phytochemical compounds, nutritional constituents, pharmacological activities, genotoxicological studies, and toxicity studies of $V$. vinifera. The data were obtained from scientific databases and search engines such as PubMed, Elsevier, Springer, Frontiers, Google Scholar, Scopus, Science Direct, and MDPI. In some countries, grapes used for traditional uses, such as drug therapy for blood-forming, anemia, allergies, wound care, colds and flu, carminative, bronchitis, diarrhea, and antiphlegm. The main phytochemical compounds in $V$. vinifera are phenolic compounds, aromatic acids, flavonoids, proanthocyanidins, and stilbenoids. Nutritional constituents can be found in grapevines, i.e., proteins, lipids, carbohydrates, minerals, and vitamins. Parts of the grapevines had a wide variety of biological activities, i.e., antioxidant, antiviral, antiplatelet, antifungal, anticataract, antiobesity, anticholinergic, anti-sunburn, anti-inflammatory, and wound-healing activities. The phytochemical compounds content in each part of the grapevines were different. Each pharmacological activity depends on the grapevine's phytochemical compounds, components used, and extraction type. However, more studies are needed regarding the genotoxicity and toxicity of $V$. vinifera.
\end{abstract}

Keywords: Vitis vinifera; phytochemical compounds; pharmacological activities; traditional uses.

(C) 2021 by the authors. This article is an open-access article distributed under the terms and conditions of the Creative Commons Attribution (CC BY) license (https://creativecommons.org/licenses/by/4.0/).

\section{Introduction}

Vitis vinifera L. is a common grape species that belongs to the Vitis genus in the Vitaceae family. $V$. vinifera has seedless and non-seedless varieties, and they are red, black, and white. $V$. vinifera species are easier to find because they dominate any other species by 90\% [1]. Grapes originate from western Asia and southern Europe [2]. Grapes are one of the largest commodities in agriculture. Therefore viticulture or grapes farming is one of the best forms of agriculture. There are about 10,000 varieties of grapes in the world. Different countries produce grapes in various forms. Countries that focus on growing fresh grapes are China, India, Iran, Egypt, Turkey, Brazil, and Mexico. In contrast, most wines are produced in Germany, France, Italy, Canada, the USA, and New Zealand. Raisin production is also quite popular with several countries such as Iran, Turkey, India, and the USA. China owns the most extensive agricultural land with over 750,000 hectares. Annual wine production can reach 77.44 million metric tons. The most considerable use of grapes is allocated for wine production, which requires $50-75 \%$, followed by fresh fruits, dried fruits, and juice [1]. 
Various kinds of phytochemicals compounds can be found at the root, stem, cane, leaf, seed, fruit, pomace, and skin. The significant compounds found are phenolic compounds, aromatic acids, flavonoids, proanthocyanidins, and stilbenoids [3-5]. Apart from bioactive compounds, nutritional constituents are also found in grapes, such as minerals, proteins, carbohydrates, vitamin C, fibers, and sugar [6-8].

In Pakistan, Italy, and Turkey, grapes are showed as traditional uses, such as drug therapy for laxatives, carminatives, colds and flu, anemia, wound-care, allergies, and bronchitis [9-13]. Many researchers have proven that the bioactive compounds found in grapes had some pharmacological activities, such as antioxidant, antidiabetic, anticancer, antibacterial, antifungal, anti-inflammatory, anti-acne, anti-aging, antihypertensive, protective effect, antiasthma, antiplatelet, antiviral, anticataract, antiobesity, anticholinergic, anti-sunburn, antihyperpigmentation, and wound-healing activities.

\section{Materials and Methods}

This article's data were obtained through search engines and scientific databases such as PubMed, Elsevier, Springer, Frontiers, Google Scholar, Scopus, Science Direct, and MDPI. The keywords used were as follows: $V$. vinifera, pharmacological effects of $V$. vinifera, antidiabetic, antioxidant, anti-aging, anti-cataract, ethnomedicinal of $V$. vinifera, the genotoxicity of $V$. vinifera, nutritional of $V$. vinifera, antispasmodic, the spasmolytic effect of grapes, phytochemicals of $V$. vinifera, anti-virus of $V$. vinifera, the toxicological study of $V$. vinifera, wound-healing of $V$. vinifera, antihypertension, and antiplatelet. The articles used in this review are articles published in the last ten years, at least 20 articles published in the previous two years. The report also has a digital object identifier (DOI).

\section{Results and Discussion}

\subsection{Traditional uses of $V$. vinifera.}

Various regions in Turkey, such as Malatya, Elazığ, and Manisa, use grapes as ethnomedicinal plants $[9,10,12]$. In the Malatya region, the grapes were beneficial in bloodforming [9], while in the Elazı $\breve{g}$ area, the grapes were beneficial for anemia [10]. For the people in Manisa, grape parts starting from seeds, branches, fruit, dried fruit, leaves, and latex can help treat allergies, wound care, anemia, cold and flu, carminatives, and bronchitis [12].

In Pakistan, grapes ( $V$. vinifera L.) are widely used as traditional medicine. In the Northwest region of Pakistan, the grapes are consumed as carminatives [14]. Sudhanoti district (Pakistan), the leaves and whole grapes can be used as a blood purifier, anti-phlegm, and quench thirst [11].

Tuscany and Bologna are areas in Italy that use wine and alcoholic beverages from $V$. vinifera $\mathrm{L}$. to treat diseases related to the digestive system [13]. Wine, vinegar, and spirit from $V$. vinifera L. are used as liniment, poultice, and mouthwash in the Republic of Cyprus [15].

$V$. vinifera L. are commonly used to treat diarrhea, varicose veins, bleeding, antiseptic, inflammatory, demulcent, diuretic, stomachic, and laxative [16]. According to research by Beni et al. (2013), raw grapes can be processed into edible products such as grape syrup [17]. 


\subsection{Phytochemical compounds of V. vinifera.}

Phytochemical compounds are various bioactive compounds found in these plants' parts and are beneficial to humans. $V$. vinifera L. contains many phenolic compounds and aromatic acid on multiple parts of the plant. The main blends of grapes are stilbenoid, flavonoids, proanthocyanidins [3], hydroxybenzoic acid [4], dan hydroxycinnamic acid [5]. Fruit grapes are rich in polyphenols, anthocyanins, flavonols, stilbenes, phenolic acids, protein, fats, and vitamins C [6].

Grape root extract contained stilbenoid compounds, which were stated by Esatbeyoglu et al. (2016): resveratrol, vitisins $\mathrm{A}$ and $\mathrm{B}$, and picaetannol, and miyabenol $\mathrm{C}$ [7]. Other stilbenoid compounds in the grape root are trans-piecid, cis-piecid, vitisinol B, viniferether A, and viniferether B ampelopsin C, ampelopsin E, hopeaphenol, dan isohopeaphenol [5].

Grape leaves contain hydroxybenzoic acid (quinic acid, gallic acid, vanilic acid, and syringic acid), hydroxycinnamic acid (caftaric acid, caffeic acid, and fertaric acid), coumarin, dihydrochalcone, monomeric stilbenes, dimeric stilbenes, trimeric stilbenes, tetrameric stilbenes, flavan-3-ol compounds including gallocatechin, catechins, procyanidins, procyanidin $\mathrm{B} 1$, procyanidin $\mathrm{A} 1$, and epicatechins. The flavonol compounds were quercetin, quercetin-3-O-glucoside, kaempferol, and myricetin. Flavone (apigenin-7-O-glucoside and luteolin-7-O-glucoside), flavanone (taxifolin, naringenin, and hesperetin), anthocyanins, and coumarin (aesculin, fraxin, aesculutin, and umbelliferone) [5], condensed tannin [18], also be found in leaves.

Grape seed extract contained the following: procyanidin, gallic acid, epicatechin, catechin, and quercetin [19]. The grape seed extract from white grape was analyzed by ultrahigh-performance liquid chromatography-tandem mass spectrometry (UHPLC-ESI-QQQMS/MS) contained flavonol glycosides [20]. In black, the grape seed was exposed to flavonol glycosides, resveratrol, and anthocyanidins [20,21]. Sochorova et al. (2020) also stated that grape seed extract contained many phenolic compounds, including caffeic acid, coumaric acid, coutaric acid, ferulic acid, and fertaric acid, routine, quercetin-3- $\beta$-D-glucoside, quercitrin, myricetin, catechin, and epicatechin [22]. Using gas chromatography-mass spectrometry (GCMS), linoleic acid, primaric acid, caffeic acid, p-hydroxy-phenylacetic acid, and gallic acid were found in grape seed extract [23].

Grape skin contained flavonols, anthocyanins [24], flavan-3-ols, stilbenes, and phenolic acid [25]. While in the grape pomace extract of $V$. vinifera L. var. Chilean was found quercetin, vanillic acid, kaempferol, syringic acid, and gallic acid [26].

Grape juice from $V$. vinifera L. var. Sangiovese detected by liquid chromatographyhigh-resolution mass spectrometry (LC-HRMS) contained caffeic acid, coumaric acid, ferulic acid, caftaric acid, coutaric acid, fertaric acid, (-) epicatechin, (+) catechin, resveratrol, procyanidin, and flavonols such as quercetin, rutin, kaempferol, quercetin-3-O-glucoside, and quercetin-3-O-glucuronide [27].

Grape stem contained gallic acid, syringic acid, caftaric acid, chioric acid, gallocatechin, caffeic acid, syringic acid, ferulic acid, procyanidin B1, procyanidin A1, procyanidin $\mathrm{C} 1$, epicatechin, catechin, catechin gallate, anthocyanin, flavanone, flavone, and flavonol (quercetin, quercetin-3-O-glucoside, and kaempferol). Stilbenic compounds are also found in stem parts such as trans-astringin, trans-resveratrol side, ampelopsin A, D, and F, vitisin $\mathrm{A}, \mathrm{B}$, and $\mathrm{C}$, and miyabenol $\mathrm{C}$ [5]. 
Grapevine canes contained gallic acid, protocatechuic acid, vanillic acid, ellagic acid, caftaric acid, coutaric acid, caffeic acid, syringic acid, ferulic acid, flavan-3-ol (procyanidin $\mathrm{B} 1$, procyanidin $\mathrm{A} 1$, procyanidin $\mathrm{C} 1$, procyanidin $\mathrm{B} 2$, catechin, and epicatechin ), and flavonols including quercetin-3-O-galactoside and quercetin-3-O-arabinose. The stilbenic compound in canes includes trans-resveratrol-2-C-glucoside, trans-resveratrol, and ampelopsin A and D [5].<smiles>Oc1ccc(/C=C/c2cc(O)cc(O)c2)cc1</smiles>

(a)<smiles>COc1cc(/C=C/c2ccc(O)cc2)cc(OC)c1</smiles>

(b)<smiles>O=C(O)c1cc(O)c(O)c(O)c1</smiles>

(c)<smiles>COc1cc(/C=C/C(=O)O)ccc1O</smiles>

(d)<smiles>O=C(O)/C=C/c1ccc(O)c(O)c1</smiles>

(e)<smiles>O=C(/C=C/c1ccc(O)c(O)c1)O[C@H](C(=O)O)[C@@H](O)C(=O)O</smiles>

(f)<smiles>O=c1c(O)c(-c2ccc(O)c(O)c2)oc2cc(O)cc(O)c12</smiles>

(h)<smiles>Oc1cc(O)c2c(c1)O[C@H](c1ccc(O)c(O)c1)[C@H](O)C2</smiles>

(j)<smiles>COc1cc(C(=O)O)cc(OC)c1O</smiles>

(g)<smiles>O=c1c(O)c(-c2ccc(O)cc2)oc2cc(O)cc(O)c12</smiles>

(i)<smiles>Oc1cc(O)c2c(c1)O[C@H](c1ccc(O)c(O)c1)[C@H](O)C2</smiles>

(k) 
<smiles></smiles>

(I)<smiles>Oc1ccc(C2Oc3cc(O)cc4c3C2c2cc(O)cc(O)c2C(c2ccc(O)cc2)C4O)cc1</smiles>

(n)<smiles>COc1c(O)cc(C2C[C@H](O)c3c(O)cc(O)c([C@@H]4c5c(O)cc(O)cc5O[C@H](c5ccc(O)cc5)[C@H]4O)c3O2)cc1O</smiles>

(m)<smiles>Oc1ccc(C2Oc3cc(O)cc(C=Cc4ccc(O)c(C5c6cc(O)cc(O)c6C(c6ccc(O)cc6)C(c6ccc(O)cc6)C5c5cc(O)cc(O)c5)c4)c3C2c2ccc(O)cc2)cc1</smiles>

(o)<smiles>Oc1ccc(C2Oc3ccc(/C=C/c4cc(O)cc5c4C(c4ccc(O)cc4)C(c4ccc(O)cc4)O5)cc3OC2c2cc(O)cc(O)c2C2c3cc(O)cc(O)c3OC2c2cc(O)cc(O)c2)cc1</smiles>

(p)

Figure 1. Several structure of phytochemicals compounds in V. vinifera L.they should be listed as (a) Resveratrol; (b) Pterostilbene; (c) Gallic acid; (d) Ferulic acid; (e) Caffeic acid; (f) Caftaric acid; (g) Syringic acid; (h) Quercetin; (i) Kaempferol; (j) (+) Catechin; (k) Epicatechin; (l) Anthocyanin; (m) Proanthocyanidin; (n) Ampelopsin A; (o) Vitisin A; (p) Vitisin B.

\subsection{Nutritional constituent.}

Various nutritional constituents were also found in grapes (V. vinifera L.). The nutritional content of grapes includes proteins, lipids, carbohydrates, minerals, and vitamins. Each part of the grapevines or any other grape-based product contains different nutrients.

Table 1. Parts of grapevines or product with nutritional constituents

Plant part or product used Seed
Nutritional constituents Minerals, proteins, lipids, carbohydrates, and fibers.
References

$[7,28]$ 


\begin{tabular}{l|l|c} 
Plant part or product used & \multicolumn{1}{|c}{ Nutritional constituents } & References \\
\hline Fruit & $\begin{array}{l}\text { Proteins, fats, vitamin C, } \\
\text { calcium, and boron } \\
\text { phosphorus. }\end{array}$ & {$[6]$} \\
\hline Raisins & $\begin{array}{l}\text { Sugars, insoluble fibers, and } \\
\text { minerals. }\end{array}$ & {$[8]$} \\
\hline Leaves & $\begin{array}{l}\text { Reducing and non-reducing } \\
\text { sugars, lipids, vitamins, and } \\
\text { minerals (K, Mg, Zn) }\end{array}$ & {$[28,29]$} \\
\hline Stem & Dietetic fibers & {$[30]$} \\
\hline Pomace & $\begin{array}{l}\text { Crude proteins, neutral } \\
\text { detergent fibers, acid } \\
\text { detergent fibers, and } \\
\text { minerals (P, Mg, S, Na, Fe, } \\
\text { Al) }\end{array}$ & $\begin{array}{l}\text { Proteins, fibers, } \\
\text { carbohydrates, pection, iron, } \\
\text { potassium, zinc, fructose, } \\
\text { and glucose }\end{array}$ \\
\hline Pomace Flour & {$[31]$}
\end{tabular}

K, Potasium; Mg, Magnesium; Zn, Zinc; P, Phosporus; S, Sulfur; Na, Sodium; Fe, Iron; Al, Aluminum.

\subsection{Pharmacological activities of V. vinifera.}

\subsubsection{Antioxidant activity.}

Grape seeds extracts were tested for their antioxidant activity using Trolox equivalent antioxidant capacity (TEAC), ferric reducing antioxidant power (FRAP), and oxygen radical absorbance capacity (ORAC) with values of $6.1 \pm 0.8 \mathrm{mmol} \mathrm{TE} / \mathrm{g}, 6.5 \pm 0.5 \mathrm{mmol} \mathrm{FE} / \mathrm{g}$, and $8.6 \pm 0.7 \mathrm{mmol} \mathrm{TE} / \mathrm{g}$ [19]. Grape seeds of ten vine varieties (Laurot, Kofranka, Hibernal, Blaufrankisch, Zweigeltrebe, Erilon, Palava, Welschriesling, Cerason, and Gewürztraminer) of $V$. vinifera antioxidant activity were tested by the 2,2-diphenyl-1-picryl-hydrazyl (DPPH), FRAP, 2,2'-azino-bis(3-ethylbenzothiazoline-6-sulfonic acid) (ABTS), and chlorophyllin free radical (CHFR) methods. The average value of antioxidant activity in ten vine varieties in 2017 showed $11.624 \mu \mathrm{g} / \mathrm{g}$ GAE on the DPPH method, $14.807 \mu \mathrm{g} / \mathrm{g}$ GAE on the FRAP method, 6518 $\mu \mathrm{g} / \mathrm{g}$ GAE on the ABTS method, and $3084 \mu \mathrm{g} / \mathrm{g}$ GAE on the CHFR form. The variety that showed antioxidant activity in each technique is Cerason [22]. Grape seeds ethanol extract had the highest antioxidant activity by testing for DPPH, FRAP, and $\alpha$-tocopherol [23].

Vitis vinifera's hydroalcoholic fruit extract observed its antioxidant activity thro $\mu \mathrm{gh}$ DPPH, ABTS, FRAP, and ORAC tests. The $\mathrm{IC}_{50}$ value of Vitis vinifera fruit showed $0.270 \pm$ $0.001 \mathrm{mg} / \mathrm{ml}$ on the DPPH method, $0.040 \pm 0.003 \mathrm{mg} / \mathrm{ml}$ on the ABTS method, $0.98 \pm 0.01$ $\mathrm{mg} / \mathrm{ml}$ on the FRAP method, and $2036 \pm 46 \mathrm{mg} / \mathrm{ml}$ on the ORAC method [32].

Grape skin extract of red color var. Hamburg Misketi had an antioxidant activity of $6,681.75 \pm 307.34 \mu \mathrm{mol} \mathrm{TE} / 100 \mathrm{~g} \mathrm{FW}$, during grape skin extract of white color var. BX1-166 is $5,602.63 \pm 257.35 \mu \mathrm{mol} \mathrm{TE} / 100 \mathrm{~g} \mathrm{FW}$ were measured using the FRAP method [33]. The antioxidant activity of grape skin extract from $V$. vinifera $\mathrm{L}$. var. Blaufränkisch and Merlot were estimated using the DPPH method. Blaufränkisch has the most extensive DPPH radical scavenging activity, which was $57.06 \pm 0.08 \%$ obtained after defoliation treatment before the veraison phase Merlot was $57.50 \pm 0.63$, which brought after defoliation treatment before blooming [34].

The antioxidant activity of grape pulp extract white and red color ( $V$. vinifera) was measured using the FRAP method. Antioxidant activity with the FRAP method for white color var. 130/1 seedless of $153.80 \pm 19.28 \mu \mathrm{mol}$ TE/100 $\mathrm{g}$ FW, white color non-seedless var. BX1166 is $285.63 \pm 44.35 \mu \mathrm{mol} \mathrm{TE} / 100 \mathrm{~g} \mathrm{FW}$, while for red color seedless $2 / \mathrm{B}-56$ it is $290.83 \pm$ 
$8.55 \mu \mathrm{mol}$ TE/100 G FW, and red color var. Hamburg Misketi (non-seedless) of 297.46 \pm 45.05 $\mu \mathrm{mol} \mathrm{TE} / 100 \mathrm{~g} \mathrm{FW}$ [33]. The antioxidant activity of pulp from seedless grape, among others, seedless red grape (California), seedless red grape (Victoria), and seedless green grape (Xinjiang) which was determined through the FRAP method in research from Liu et al. (2018), stated that seedless red grape (California) had FRAP values with $7.880 \mu \mathrm{mol} F e$ (II) / g FW > seedless red grape (Victoria) and seedless green grape [35].

\subsubsection{Anti-inflammatory activity.}

Leaf extract of $V$. vinifera at high doses showed vigorous anti-inflammatory activity, demonstrated by edema reduction at a dose of $400 \mathrm{mg} / \mathrm{kg}(50.02 \%)$ at 4 hours via carrageenaninduced hind paw edema test. Components that played an anti-inflammatory role were quercetin, kaempferol, resveratrol, and quinic acid [18]. Leaf extract of $V$. vinifera var. Fetească Neagră with high concentrations had anti-inflammatory activity by reducing inflammatory cytokines (IL-8, IL-6, IL-1ß) in lipopolysaccharide-induced cells [36]. According to Balea et al. (2020), Grape pomace from $V$. vinifera L. var. Fetească Neagră and Pinot noir also presented anti-inflammatory activity. Compounds that played an important role as an anti-inflammatory agent were miricetol and quercitrin [37].

Cádiz-Gurrea et al. (2017) showed that grape seed extracts with concentrations of over 50 and $60 \mathrm{mg} / \mathrm{ml}$ showed anti-inflammatory activity by reducing mRNA expression of monosit chemoattractant protein-1 (MCP-1) in human umbilical vein endothelial cell (HUVEC) [19]. Grape root extract $(20 \mu \mathrm{g} / \mathrm{mL})$ was reported by Esatbeyoglu et al. (2016) research to have antiinflammatory activity by lowering the Nf-kb target genes IL- $1 \beta$ and inducible nitric oxide synthase (iNOS) in lipopolysaccharide-induced macrophages [7].

V. vinifera var. Exalta and Albarossa showed anti-inflammatory activity by inhibiting IL-8 on TNF- $\alpha$-induced released with low IC50, Albarossa skin extract (IC50 $51.47 \mu \mathrm{g} / \mathrm{ml}$ and Exalta skin extract ( $\mathrm{IC}_{50} 9.77 \mu \mathrm{g} / \mathrm{ml}$ ). The anti-inflammatory activity is related to high levels of anthocyanins in Albarossa skin, flavonols in Exalta seeds, and procyanidins in both varieties [24].

In inflammatory skin disease, IL-8 is a chemokine produced by keratinocytes during the inflammation process. Aqueous leaf extract of $V$. vinifera $(50 \mu \mathrm{g} / \mathrm{ml})$ showed a decrease in the release of IL-8 in TNF- $\alpha$ (IC50 $2.60 \mu \mathrm{g} / \mathrm{ml})$ and lipopolysaccharide (LPS) (IC $5014.04 \mu \mathrm{g} / \mathrm{ml}$ ) induced by inflammation [38].

The phenol and proanthocyanidin compounds were found in Turkish and Portuguese raisin had anti-inflammatory activity. Turkish and Portuguese raisins' hydroalcoholic extract showed an anti-inflammatory mechanism by inhibiting the release of TNF $\alpha$-induced IL-8 release in human gastric epithelial cells. Turkish raisin extracts were able to inhibit the Nf-kB pathway [8].

\subsubsection{Antifungal activity.}

Pterostilbene contained in grape pomace and leaves have antifungal capabilities $[39,40]$. This was proven by testing $16 \mu \mathrm{g} / \mathrm{ml}$ of pterostilbene placed on poly (lactic-coglycolic) acid nanoparticles (PLGA NP's) to reduce C. albicans biofilm formation by $63 \%$ and $50 \%$ reduction in mature biofilms [39].

Fraternale et al. (2015) stated that ethanol extract of grape (V. vinifera L. var. Sangiovese) tendrils has antifungal activity. The types of fungi that can against by grape 
tendrils were Botrytis cinerea, Alternaria solani, Rhizoctonia solani, Fusarium solani, F. coeruleum, $F$. sporotrichioides, $F$. culmorum, $F$. oxysporum, $F$. tabanicum, and $F$. verticillioides [41].

Grape (V. vinifera L.) seeds extract had antifungal activity against Candida albicans, Malassezia furfur, and Trichophyton mentagrophytes [42-44]. Compound that act as antifungal was flavan-3-ols $[43,44]$. The higher extract concentration gave greater inhibition zone diameter formed against $C$. albicans [42].

The contents of grape ( $V$. vinifera $\mathrm{L}$.) canes were 3,4'-dimethoxy-resveratrol and 3,5dimethoxy-resveratrol. Both compounds showed antifungal activity with a minimum inhibitory concentration of 29-37 $\mu \mathrm{g} / \mathrm{ml}$ against Candida sp. [45].

\subsubsection{Antibacterial activity.}

Grape (V. vinifera L.) seed extract exhibited antibacterial activity [4,42]. The higher extract concentration showed higher inhibition zone diameter against Streptococcus mutants [42]. Grape seeds extracts of $V$. vinifera var. Muscat Hamburg and Merlot have a strong ability to fight the bacteria Leuconostor sp. and Micrococcus sp. with MIC of 380 and $450 \mu \mathrm{g} / \mathrm{ml}$ [4].

The antibacterial activity of $V$. vinifera var. Fetească Neagră leaf extract was indicated by inhibition zone diameter on Porphyromonas gingivalis ATCC 33277, which was $13 \pm 1.41$ mm, Enterococcus faecalis ATCC 29212 and Staphylococcus aureus ATCC 25923 was $12 \pm$ $1.41 \mathrm{~mm}$, Streptococcus mutans ATCC 25175 and Escherichia coli ATCC 25922 was $11.5 \pm$ $0.71 \mathrm{~mm}$. Meanwhile, the tendril extract of $V$. vinifera var. Fetească Neagră, antibacterial activity was seen by inhibition zone diameter in bacterial or fungal strains Porphyromonas gingivalis ATCC 33277, Enterococcus faecalis ATCC 29212 and Streptococcus mutans ATCC 25923 were $10.00 \pm 0.00 \mathrm{~mm}, S$. aureus ATCC 25923 was $14.5 \pm 0.71 \mathrm{~mm}$, and E. coli ATCC 25922 was ten $\pm 1.41 \mathrm{~mm}$. The antibacterial activity on the leaves and tendrils of $V$. vinifera is possible due to the high concentration of flavonoids and stilbenes in these sites [36].

Grape ( $V$. vinifera L.) skin extract had intense antibacterial activity [4,23,34]. $V$. vinifera var. Muscat Hamburg had strong antibacterial activity against Lactococcus sp. and Streptococcus sp. with minimum inhibitory concentration (MIC) of 4500 and $4250 \mu \mathrm{g} / \mathrm{ml}$. $V$. vinifera var. Pinot Noir and Fetească Neagră against Bacillus sp. with MIC $3750 \mu \mathrm{g} / \mathrm{ml}$ and $4800 \mu \mathrm{g} / \mathrm{ml}$ [4]. Antibacterial activity was also found in the Blaufrankisch and Merlot variants; both variants had antibacterial activity against E. coli, P. aeruginosa, B. subtilis, and S. aureus [34].

White grape (V. vinifera L.) juice could inhibit the growth $S$. aureus, E. coli, and $P$. aeruginosa [3]. Also, Leal et al. (2020) stated that grape stem extract from white grape also has strong antibacterial activity against $S$. aureus and E. faecalis [46].

\subsubsection{Antidiabetic activity.}

Grape seeds, skins, and flesh from V. vinifera L. var Seyval Blanc, Hibernal, Pinot Gris, Freiminer, Roter Taminer, Regent, and Rondo presented antidiabetic activity by $\mathrm{IC}_{50}$ ranging from 0.27 to $1.13 \mathrm{mg}$ dry sample/ml in inhibiting $\alpha$-amylase and $\alpha$-glycosidase [25]. OstbergPotthoff et al. (2019) also reported red grape juice activity concentration in $\alpha$-amylase and $\alpha$ glycosidase; the best action was anthocyanin fraction, followed by co-pigment fraction red grape juice concentrate [47]. Grape seeds, skins, and stems from var. Pusa Navrang and Merlot were able to increase insulin secretion in isolated mice pancreatic islets 2-8 fold from regular 
[48]. Gharib et al. (2013) exposed that cyanidin and delphinidin compounds were found in $V$. vinifera $\mathrm{L}$. to reduce the rate of albumin and HbA1c measured in vivo (mice diabetic) and in vitro (ELISA assay) [49]. Increased insulin secretion also occurred in alloxan-induced diabetic mice treated with grape skin extract [50].

\subsubsection{Antihypertension activity.}

Skin grape aqueous extract (Vitis vinifera L.) could prevent increasing systolic blood pressure in spontaneously hypertensive rats measured using the tail-cuff method. The results demonstrated that hypertensive rats had blood pressure $>200 \mathrm{mmHg}$, and hypertensive rats treated with grape skin extract had blood pressure $<150 \mathrm{mmHg}$ [51]. Godse et al. (2010) stated that the myricetin content found in grape raisin could reduce systolic blood pressure in fructoseinduced rats [52] and also in deoxycortisone acetate (DOCA)-salt-hypertensive rats [53].

\subsubsection{Antiobesity and fatty liver activity.}

Grape skin extract could prevent weight gain when weight gain causes obesity and fatty liver risk[54,55]. Fan et al. (2019) reported that grape skin extract of Vitis vinifera L., which contains proanthocyanidins, could act as an anti-fatty liver high-fat-diet-induced NAFLD mice. Prevention of fatty liver, apart from weight loss, was also followed by reducing alanine transaminase (ALT), alkaline phosphatase (ALP), aspartate transaminase (AST), total protein (TP), total cholesterol (TC), low-density lipoproteins (LDL), and triglyceride (TG) values, and decreasing the number of abnormal cells (lesion area) [56]. Ethanolic grape seed extract from the Muscat variety could also reduce blood serum levels in diabetic rats [57].

\subsubsection{Antiviral activity.}

\subsubsection{Anti-influenza.}

The procyanidin contained in grape seeds shows anti-influenza activity. Procyanidin concentration of $6.25-25 \mu \mathrm{g} / \mathrm{ml}$ could inhibit viral replication as measured by plaque inhibition assay. It can also work as an anti-influenza by inhibiting the accumulation of autophagosomes induced against influenza virus by reducing the ratio LC3II (light chain of the microtubuleassociated protein) $\beta$-actin in the treatment group [58].

\subsubsection{Anti-MERS-CoV.}

Resveratrol (trans-3,5, 4 '- trihydroxystilbene) is one of the compounds in grapes ( $V$. vinifera L.), reducing cell death MERS-CoV. Moreover, neutral red uptake (NRU) assays with resveratrol concentrations of $250-125 \mu \mathrm{M}$. Besides, resveratrol also suppressed replication of MERS-CoV RNA in high concentrations. Concomitant administration of resveratrol with MERS-CoV or after that had been shown to stop MERS-CoV infection [59].

\subsubsection{Anticataract activity.}

Grapes (V. vinifera L.) contained citronellol, which acts against glucose toxicity through an aldose reductase inhibitor mechanism, which prevents the onset of diabetic cataract [60]. Additionally, according to Higashi et al. (2018), the resveratrol content found in grapes 
could also act as an anti-cataract, as tested on 7-week-old male Wistar type 1 diabetes-induced by preventing oxidative damage of lens protein [61].

\subsubsection{Antipyretic activity.}

The antipyretic activity was determined using the yeast-induced pyrexia model. It was found that the effect of $V$. vinifera leaf extract was able to reduce the rectal temperature at a dose of $100 \mathrm{mg} / \mathrm{kg}, 200 \mathrm{mg} / \mathrm{kg}$, and $400 \mathrm{mg} / \mathrm{kg}$ after $22 \mathrm{~h}$ of injection of yeast. And a significant reduction occurred at doses of 200 and $400 \mathrm{mg} / \mathrm{kg}$ after $23 \mathrm{~h}$ of injection [18].

\subsubsection{Antinociceptive activity.}

Aqueous ethanol extract of $V$. vinifera $\mathrm{L}$. through acetic-acid induced writhing and formalin test showed antinociceptive activity. In acetic-acid-induced writhing in mice, the extract produced an inhibitory effect of $65.5 \%$. In contrast, the formalin test (chronic pain model) could reduce licking time and inhibit licking response [18].

\subsubsection{Prevent bone loss activity.}

Seeds extract of red grape, which contained proanthocyanidin was able to prevent bone loss. The proanthocyanidin reduced inflammatory osteolysis, inhibiting osteoclast differentiation, apoptosis and promoting proliferation in mice induced by lipopolysaccharide (LPS) [62].

\subsubsection{Anticholinergic activity.}

Based on the research of Tkacz et al. (2019), grape seeds, skins, and flesh from $V$. vinifera L. var Seyval Blanc, Hibernal, Pinot Gris, Freiminer, Roter Taminer, Regent, and Rondo can inhibit acetylcholinesterase (AChE) and butyrylcholinesterase (BuChE). Grape skin var Rondo has the highest AChE-inhibition activity of 55.33\%. The highest BuChE-inhibition activity of $36.84 \%$ was grape seeds var. Freiminer. In general, Rondo skin had the most potent anticholinergic activity [25].

\subsubsection{Anticancer activity.}

\subsubsection{Prostate cancer.}

Proanthocyanidin (structure of epicatechin octamer) contained in grape stems is related to the anticancer activity. Anti prostate cancer activity was proven by the presence of cell growth inhibition from prostate cancer cells. Another proanthocyanidin anticancer mechanism is to increase apoptotic activity in prostate cancer cells and suppress the expression of prostate cancer-promoting gene fatty acid-binding protein five at mRNA and protein levels [63].

\subsubsection{Skin cancer.}

The high concentration of skin and seed extract from $V$. vinifera $L$. increases A431 skin cancer cells' growth inhibition. The mechanism of its inhibition can be seen through induction of cytotoxicity, measured the cytotoxic effect of the two extracts via MTT assay using A431 cells and human keratinocytes cell line $(\mathrm{HaCaT})$. The $\mathrm{IC}_{50}$ values of grape seeds and skin extract on A431 cells were $111.11 \mu \mathrm{g} / \mathrm{ml}$ and $319.14 \mu \mathrm{g} / \mathrm{ml}$, followed by increases in reactive 
oxygen species (ROS) production induced apoptotic cells, which showed by green fluorescence through a fluorescence microscope [64]. However, Decean et al. (2016) said that grape seeds extract could induce apoptotic cells but did not increase ROS production but decreased it [65].

\subsubsection{Breast cancer.}

Grape pomace from $V$. vinifera $\mathrm{L}$. var. Negroamaro produced a phenolic fraction of grape seeds extract, which would induce apoptosis of cell death in MCF-7 breast cancer cells with an adequate concentration of $25-50 \mu \mathrm{g}$ GAE/ml [66]. Grape seeds extract was also a chemopreventive agent that works by increasing transient gap-junction-intercellular communications (GJIC), increasing connexin-43 gene (cx34) expression in MCF-7 cells, relocating connexin-43 protein ( $\mathrm{Cx} 43)$, and suppress estrogen [66,67]. The stilbenoid compounds in grape extract had antiproliferative activity on breast cancer cells [68].

\subsubsection{Hepatocelluler carcinoma.}

The grape cane extract contained natural stilbene oligomers (resveratrol, ampelopsin, trans-e-viniferin), which had anticancer activity on hepatocellular carcinoma cells reducing the viability of HepG2 and Hep3B, and chemoprevention. Treatment of liver cancer by increasing ROS intracellular, caspase- 3 activity, and inducing death of HepG2 by a caspase-dependent mechanism [69].

\subsubsection{Oral squamous carcinoma.}

Grape seeds extract with $\mathrm{IC}_{50}$ of $245.984 \mu \mathrm{g} / \mathrm{ml}$ could induce apoptosis in oral squamous cell carcinoma (KB cell) as measured by cell death detection ELISA plus kit. The apoptotic effect was given by grape seeds extract was the highest at $69.56 \%$. Also, grape seed extract enhanced DNA fragmentation [2].

\subsubsection{Anti-Alzheimer activity.}

Grape skin, seeds, and fruit had anti-Alzheimer's activity by various mechanisms [7072]. Grape powder and ethanolic extract as anti-Alzheimer's agents worked by recovering memory deficit and improved recall in Alzheimer's rats, followed by decreasing mRNA expression of amyloid precursor protein and clearing the tau tangles [70,72].

\subsubsection{Anti-acne activity.}

Acne vulgaris is a skin problem caused by Propionibacterium acnes. Based on Nelson's research, extracts from grape leaves had an anti-acne activity shown by $\mathrm{MIC}_{50}$ and $\mathrm{MIC}_{90}$ values of $64 \mu \mathrm{g} / \mathrm{ml}$ when against $P$. acnes [73].

\subsubsection{Anti-aging activity.}

Aging on the skin may be caused by radiation and pollutants. Based on Cronin's research, those grape seeds extract from $V$. vinifera $\mathrm{L}$. containing t-resveratrol could slow the onset of aging and had the potential to be an ingredient for anti-aging products [74]. However, Based on Sharif's research, seed extract of Vitis vinifera L. var. Muscat Hamburg could be an ingredient for an anti-aging product because it is rich in antioxidants and works by increasing skin elasticity [75]. 


\subsubsection{Anti-Sunburn activity.}

The anti-sunburn activity of resveratrol from $V$. vinifera $\mathrm{L}$. was proven by skin color parameters measured using a CM-2500d spectrophotometer. In the skin color parameters, there was a decrease in degrees of lightness ( $\mathrm{L}^{*}$ ) from 64.20 to 59.3 and an increase in degrees of green to red $(\mathrm{a} *)$ from 7.51 to 13.43 in the test group with resveratrol treatment on skin exposed to UV irradiation for $4 \mathrm{~d}$, which indicated reducing sunburn in the test group [76].

\subsubsection{Anti-hyperpigmentation and skin lightening activity.}

The anti-hyperpigmentation activity of red vine leaf extract of $V$. vinifera L., which contained flavonoids, resveratrol, gallic acid, chlorogenic acid, and epicatechin, could inhibit tyrosinase with $\mathrm{IC}_{50} 3.84 \mathrm{mg} / \mathrm{ml}$, where tyrosinase was responsible for skin pigmentation [77]. Skin lightening activity showed on the Yucatan swine test on dark skin, treatment for eight weeks, five days per week, and twice a day using a topical preparation containing $1 \%$ resveratrol showed skin lightening without any irritation [76].

\subsubsection{Anti-asthma activity.}

Gallic acid contained in the alcoholic extract of dried fruits $V$. vinifera acts as an antiasthma drug. The mechanism of the extract's action as an anti-asthma such as inhibition of histamine release, reduction of cytokine production (IL-4, IL-5, TNF, IL-1 $\beta$ ) by alcoholic extract of dried fruits $V$. vinifera (concentration $31 \mathrm{mg} / \mathrm{kg}$ and $42.5 \mathrm{mg} / \mathrm{kg}$ ). Followed by another mechanism, i.e., improves lung functioning with evidence of increasing lumen size and decreasing cellular infiltration and reduced numbers of leukocytes and white blood cells (eosinophils and neutrophils) [6].

\subsubsection{Antiplatelet activity.}

Grape skin extract, which contained poliflavan-3-ol, could act as an antiplatelet by inhibiting human platelet aggregation [78]. Based on research on antiplatelets by Bijak et al. (2019), where grape seeds extract was tested using the vasodilator-stimulated phosphoprotein (VASP) assay, it could reduce adenosine diphosphate (ADP)-induced aggregation in white blood [79].

\subsubsection{Wound-healing activity.}

Grape oil contained $20.10 \pm 0.02 \mathrm{mg} / \mathrm{g}$ of hydroxyproline, which acts as a woundhealing as evidenced by reducing wound area on the $13^{\text {th }}$ day by $84.6 \%$ after grape oil administration [80]. In previous research, Nayak et al. (2010) exposed that grape skin also had wound-healing activity, where the wound area was closed on the $13^{\text {th }}$ day [81].

\subsubsection{Antispasmodic activity}

Leaves extract from $V$. vinifera $\mathrm{L}$. had a spasmolytic effect $[82,83]$. According to the research of Glerisk et al., the isolated compound from grape seeds extract was 1- (3 ', 4'dihydroxyphenyl) -3- (2 ", 4", 6 "-trihydroxyphenyl) -propan-2-ol, which had potential as an antispasmodic by decreasing the concentration of histamine-induced contraction [84]. 


\subsubsection{Protective effect.}

\subsubsection{Colonprotective effect.}

Grape seeds have a protective effect against colitis $[21,85]$. Grape seeds were provided protective effect by suppressing inflammation and apoptosis [85]. According to Niknami et al. (2020), hydroalcoholic black grape seeds extract and black grape seeds oil also had a protective effect by decreasing colon weight, ulcer index, and total colitis index [21]. The grape root extract has a protective impact towards oxidative DNA damage by hydrogen peroxide on human colonic adenocarcinoma cells (HT-29 cells), where the extract could prevent $\mathrm{H}_{2} \mathrm{O}_{2}$ induced-DNA damaged as evidenced by a comet assay [7].

\subsubsection{Neuroprotective effect.}

Research from Jin et al. (2013) reported that grape seeds extract administered for 12 weeks at a concentration of 100 or $250 \mathrm{mg} / \mathrm{kg}$ in high-fat diet-induced mice could increase intraepidermal nerve fiber density, a potential nerve protective [86]. In colorectal cancer treatment, oxaliplatin is used as an anticancer agent. However, oxaliplatin could induce neurotoxicity. Hydroalcoholic extract of $V$. vinifera red leaf can protect nerve cells from oxidative damage by decreasing $\mathrm{O}_{2}^{-}$production and preventing lipid peroxidation of protein. Administration of $V$. vinifera $\mathrm{L}$. extract at a daily dose of $300 \mathrm{mg} / \mathrm{kg}$ can reduce the pain caused by oxaliplatin [87]. Based on Ismail et al. (2015), grape seed oil was indicated to have a neuroprotective effect, which could suppress inflammation and inhibit iNOS and XO expression in gamma-irradiated rats induced by carbon tetrachloride and could cause neurotoxicity [88]. Besides, Lakshmi et al. (2014) stated that hydroalcoholic extract from black grapefruit could regulate antioxidant levels in rat brains induced by aluminum [89].

\subsubsection{Cardioprotective effect.}

The pomace of pinotted and unfermented $V$. vinifera L. var. Fetească Neagră was able to against isoprenaline (ISO)-induced myocardial ischemia on rats by reducing oxidative stress markers [90]. Polyphenol extract of $V$. vinifera L. var. Fetească Neagră and $V$. vinifera L. var. Aglianico N. could increase antioxidant capacity in rats treated with doxorubicin $[91,92]$. The cardioprotective effect of the grape comes from phenolic compounds [90,92].

Abdelsalam et al. (2019) stated ethanolic grape seed extract could be used for cardiorenal injury. Phenolic compounds of this extract could reduce total cholesterol, triglycerides (TGL), high-density lipoprotein (HDL), LDL, high-sensitivity C-reactive protein (hs-CRP), serum urea, creatinine, and blood urea nitrogen (BUN). Increases followed them in gene expression of Nrf2 [93].

\subsubsection{Hepatoprotective effect.}

The polyphenol compounds found in grape skin extract could improve hepatic steatosis and adiposity in high-fat-diet mice by regulating mRNA expression (changing lipogenesis and $\beta$-oxidation genes) [94]. Grape seeds extract was able to guard liver injury caused by alcohol induction. Grape seeds extract administered to rats induced by $20 \%$ ethanol in rats could decrease AST and LDH [95]. In rats induced by paracetamol treated by grape dried seed, the ALP level could be reduced [96]. 


\subsubsection{Cytotoxic effect.}

Grape seeds and skin extracts from the muscat family (V. vinifera L.) had a cytotoxicity effect measured by MTT assay with $\mathrm{IC}_{50}$ of $111.1 \mu \mathrm{g} / \mathrm{ml} 319.4 \mu \mathrm{g} / \mathrm{ml}$ on A431 cells but not toxic to HaCaT cells [64]. The phenolic fraction of grape seeds extract obtained from grape pomace var. Negroamora with high concentrations (75-100 $\mu \mathrm{g}$ GAE/ml) showed cytotoxic activity in breast cancer cells, as evidenced by late apoptosis [66]. Aqueous extract from $V$. vinifera $\mathrm{L}$. var. Carbanet Sauvignon marc with a volume fraction of $3.2 \%$ had a cytotoxic effect by reducing cell viability by $20 \%$, as evidenced by MTT assay [97].

Sales et al. (2018) reported that grape pomace extract from Vitis vinifera L. var Pinot Noir had a cytotoxic effect as indicated by an IC50 of $200 \mu \mathrm{g} / \mathrm{mL}$, followed by $80 \%$ HepG 2 cell lysis after incubating for 24 hours with grape pomace extract [98]. In contrast, according to Liang et al. (2014), Vitis vinifera fruit at $150 \mathrm{mg} / \mathrm{mL}$ had no cytotoxicity effect on HepG2 cells tested by methylene blue assay [99].

\subsection{Genotoxocicity test.}

Lluis et al. (2011) showed that skin and seed extract of $V$. vinifera L. var. Syrah was slightly mutagenic, proven by a bacterial reverse mutation test using bacterial strains of Salmonella typhimurium (TA 1535, TA 1537, TA 98, TA 100), where there was increasing in the number of revertant colonies in the TA 1537 strain $(5 \mathrm{mg} / \mathrm{plate})$. Apart from this test, the degree of genotoxicity of grape skin and seed extract was also tested through an in vivo test, namely the micronucleus test. However, the degree of genotoxicity could not be determined because several micronucleated cells did not appear after $72 \mathrm{~h}$ of incubation with the extract [100].

\subsection{Toxicity study.}

Grape seeds and skin extract were measured for their acute oral toxicity through a limit test. The tests were carried out on six female Wistar rats, of which three of them as a control group (p.o saline solution), and the other three were treated using extracts dissolved in saline solution (p.o $5000 \mathrm{mg} / \mathrm{kg}$ ). All three rats showed no toxic effect after 14 days of treatment [100].

\section{Conclusions}

Vitis vinifera L., with its various varieties, Vitis vinifera L still has phytochemical compounds similar to each other. The major phytochemical compounds are stilbenoid, phenolic compounds, aromatic acids (hydroxycinnamic and hydroxybenzoic acid), flavonoids, proanthocyanidin. Every part of $V$. vinifera L. was rich in phytochemical compounds, which differ from one component to another. Every part and compound contained therein had benefits for humans, as evidenced by the many pharmacological activities found. The pharmacological activity depends on the part of the grapevines and the type of extract used. Therefore, $V$. vinifera can be beneficial for humans in traditional use and research development. There is a lack of recent studies on genotoxicity and toxicity. Much recent research is needed regarding the genotoxicity and toxicology study of $V$. vinifera. 


\section{Funding}

This research received no external funding.

\section{Acknowledgments}

The authors are grateful for the provision and supporting facilities by the Department of Pharmaceutical Biology, School of Pharmacy, Bandung Institute of Technology, Indonesia.

\section{Conflicts of Interest}

The authors declare no conflict of interest.

\section{References}

1. Venkitasamy, C.; Zhao, L.; Zhang, R.; Pan, Z. Chapter 6 - Grapes. In Integrated Processing Technologies for Food and Agricultural By-Products, Pan, Z., Zhang, R., Zicari, S., Eds. Academic Press: 2019; 133-163, https://doi.org/10.1016/B978-0-12-814138-0.00006-X.

2. Aghbali, A.; Hosseini, S.V.; Delazar, A.; Gharavi, N.K.; Shahneh, F.Z.; Orangi, M.; Bandehagh, A.; Baradaran, B. Induction of apoptosis by grape seed extract (Vitis vinifera) in oral squamous cell carcinoma. Bosnian journal of basic medical sciences 2013, 13, 186, https://doi.org/10.17305/bjbms.2013.2360.

3. Filocamo, A.; Bisignano, C.; Mandalari, G.; Navarra, M. In Vitro Antimicrobial Activity and Effect on Biofilm Production of a White Grape Juice (Vitis vinifera) Extract. Evid. Based Complement. Alternat. Med. 2015, 2015, 856243, https://doi.org/10.1155/2015/856243.

4. Radulescu, C.; Buruleanu, L.C.; Nicolescu, C.M.; Olteanu, R.L.; Bumbac, M.; Holban, G.C.; Simal-Gandara, J. Phytochemical Profiles, Antioxidant and Antibacterial Activities of Grape (Vitis vinifera L.) Seeds and Skin from Organic and Conventional Vineyards. Plants 2020, 9, https://doi.org/10.3390/plants9111470.

5. Goufo, P.; Singh, R.K.; Cortez, I. A Reference List of Phenolic Compounds (Including Stilbenes) in Grapevine (Vitis vinifera L.) Roots, Woods, Canes, Stems, and Leaves. Antioxidants 2020, 9, https://doi.org/10.3390/antiox9050398.

6. Arora, P.; Ansari, S.H.; Najmi, A.K.; Anjum, V.; Ahmad, S. Investigation of anti-asthmatic potential of dried fruits of Vitis vinifera L. in animal model of bronchial asthma. Allergy, Asthma \& Clinical Immunology 2016, 12, 42, https://doi.org/10.1186/s13223-016-0145-x.

7. Esatbeyoglu, T.; Ewald, P.; Yasui, Y.; Yokokawa, H.; Wagner, A.E.; Matsugo, S.; Winterhalter, P.; Rimbach, G. Chemical Characterization, Free Radical Scavenging, and Cellular Antioxidant and Anti-Inflammatory Properties of a Stilbenoid-Rich Root Extract of $\langle i>$ Vitis vinifera</i $\rangle$. Oxid. Med. Cell. Longev. 2016, 2016, 8591286, https://doi.org/10.1155/2016/8591286.

8. Di Lorenzo, C.; Sangiovanni, E.; Fumagalli, M.; Colombo, E.; Frigerio, G.; Colombo, F.; Peres de Sousa, L.; Altindişli, A.; Restani, P.; Dell'Agli, M. Evaluation of the Anti-Inflammatory Activity of Raisins (Vitis vinifera L.) in Human Gastric Epithelial Cells: A Comparative Study. Int. J. Mol. Sci. 2016, 17, https://doi.org/10.3390/ijms17071156.

9. Tetik, F.; Civelek, S.; Cakilcioglu, U. Traditional uses of some medicinal plants in Malatya (Turkey). J. Ethnopharmacol. 2013, 146, 331-346, https://doi.org/10.1016/j.jep.2012.12.054.

10. Hayta, S.; Polat, R.; Selvi, S. Traditional uses of medicinal plants in Elazığ (Turkey). J. Ethnopharmacol. 2014, 154, 613-623, https://doi.org/10.1016/j.jep.2014.04.026.

11. Ishtiaq, M.; Mahmood, A.; Maqbool, M. Indigenous knowledge of medicinal plants from Sudhanoti district (AJK), Pakistan. J. Ethnopharmacol. 2015, 168, 201-207, https://doi.org/10.1016/j.jep.2015.01.054.

12. Sargin, S.A.; Selvi, S.; López, V. Ethnomedicinal plants of Sarigöl district (Manisa), Turkey. J. Ethnopharmacol. 2015, 171, 64-84, https://doi.org/10.1016/j.jep.2015.05.031.

13. Egea, T.; Signorini, M.A.; Bruschi, P.; Rivera, D.; Obón, C.; Alcaraz, F.; Palazón, J.A. Spirits and liqueurs in European traditional medicine: Their history and ethnobotany in Tuscany and Bologna (Italy). $J$. Ethnopharmacol. 2015, 175, 241-255, https://doi.org/10.1016/j.jep.2015.08.053. 
14. Adnan, M.; Ullah, I.; Tariq, A.; Murad, W.; Azizullah, A.; Khan, A.L.; Ali, N. Ethnomedicine use in the war affected region of northwest Pakistan. Journal of Ethnobiology and Ethnomedicine 2014, 10, 16, https://doi.org//10.1186/1746-4269-10-16.

15. Lardos, A.; Heinrich, M. Continuity and change in medicinal plant use: The example of monasteries on Cyprus and historical iatrosophia texts. J. Ethnopharmacol. 2013, 150, 202-214, https://doi.org/10.1016/j.jep.2013.08.026.

16. Urbi, Z.; Hossain, M.S.; Rahman, K.M.H.; Zayed, T.M. Grape: a medicinal fruit species in the holy Qur'an and its ethnomedicinal importance. World Applied Sciences Journal 2014, 30, 253-265, https://doi.org/10.5829/idosi.wasj.2014.30.03.81114.

17. Beni, B.N.; Babaheydari, A.K.; Beni, A.N.; Beni, M.T.; Ansari, F. Qualitative and Quantitative Analysis of the White Soil: Implication for Production of Grape Syrup. World Applied Sciences Journal 2013, 21, 18291834, https://doi.org/10.5829/idosi.wasj.2013.21.12.1988.

18. Aouey, B.; Samet, A.M.; Fetoui, H.; Simmonds, M.S.J.; Bouaziz, M. Anti-oxidant, anti-inflammatory, analgesic and antipyretic activities of grapevine leaf extract (Vitis vinifera) in mice and identification of its active constituents by LC-MS/MS analyses. Biomedicine \& Pharmacotherapy 2016, 84, 1088-1098, https://doi.org/10.1016/j.biopha.2016.10.033.

19. Cádiz-Gurrea, M.D.; Borrás-Linares, I.; Lozano-Sánchez, J.; Joven, J.; Fernández-Arroyo, S.; SeguraCarretero, A. Cocoa and Grape Seed Byproducts as a Source of Antioxidant and Anti-Inflammatory Proanthocyanidins. Int. J. Mol. Sci. 2017, 18, https://doi.org//10.3390/ijms18020376.

20. Pérez-Navarro, J.; Cazals, G.; Enjalbal, C.; Izquierdo-Cañas, P.M.; Gómez-Alonso, S.; Saucier, C. Flavanol Glycoside Content of Grape Seeds and Skins of Vitis vinifera Varieties Grown in Castilla-La Mancha, Spain. Molecules 2019, 24, https://doi.org/10.3390/molecules24214001.

21. Niknami, E.; Sajjadi, S.E.; Talebi, A.; Minaiyan, M. Protective Effect of Vitis vinifera (Black Grape) Seed Extract and Oil on Acetic Acid-Induced Colitis in Rats. Int. J. Prev. Med. 2020, 11, 102, https://doi.org/10.4103/ijpvm.IJPVM_362_19.

22. Sochorova, L.; Prusova, B.; Jurikova, T.; Mlcek, J.; Adamkova, A.; Baron, M.; Sochor, J. The Study of Antioxidant Components in Grape Seeds. Molecules 2020, 25, https://doi.org/10.3390/molecules25163736.

23. Felhi, S.; Baccouch, N.; Ben Salah, H.; Smaoui, S.; Allouche, N.; Gharsallah, N.; Kadri, A. Nutritional constituents, phytochemical profiles, in vitro antioxidant and antimicrobial properties, and gas chromatography-mass spectrometry analysis of various solvent extracts from grape seeds ( Vitis vinifera L.). Food Sci. Biotechnol. 2016, 25, 1537-1544, https://doi.org/10.1007/s10068-016-0238-9.

24. Colombo, F.; Di Lorenzo, C.; Regazzoni, L.; Fumagalli, M.; Sangiovanni, E.; Peres de Sousa, L.; Bavaresco, L.; Tomasi, D.; Bosso, A.; Aldini, G.; Restani, P.; Dell'Agli, M. Phenolic profiles and anti-inflammatory activities of sixteen table grape (Vitis vinifera L.) varieties. Food Funct. 2019, 10, 1797-1807, https://doi.org/10.1039/C8FO02175A.

25. Tkacz, K.; Wojdyło, A.; Nowicka, P.; Turkiewicz, I.; Golis, T. Characterization in vitro potency of biological active fractions of seeds, skins and flesh from selected Vitis vinifera L. cultivars and interspecific hybrids. $J$. Funct. Foods 2019, 56, 353-363, https://doi.org/10.1016/j.jff.2019.03.029.

26. Cotoras, M.; Vivanco, H.; Melo, R.; Aguirre, M.; Silva, E.; Mendoza, L. In Vitro and in Vivo Evaluation of the Antioxidant and Prooxidant Activity of Phenolic Compounds Obtained from Grape (Vitis vinifera) Pomace. Molecules 2014, 19, https://doi.org/10.3390/molecules191221154.

27. Fia, G.; Gori, C.; Bucalossi, G.; Borghini, F.; Zanoni, B. A Naturally Occurring Antioxidant Complex from Unripe Grapes: The Case of Sangiovese (v. Vitis vinifera). Antioxidants 2018, 7 , https://doi.org/10.3390/antiox7020027.

28. Mateo, J.J.; Maicas, S. Valorization of winery and oil mill wastes by microbial technologies. Food Res. Int. 2015, 73, 13-25, https://doi.org//10.1016/j.foodres.2015.03.007.

29. Romero, I.; García-Escudero, E.; Martín, I. Effects of Leaf Position on Blade and Petiole Mineral Nutrient Concentration of Tempranillo Grapevine (\&lt;em\&gt;Vitis vinifera\&lt;/em\&gt; L.). American Journal of Enology and Viticulture 2010, 61, 544, https://doi.org/10.5344/ajev.2010.09091.

30. Chikwanha, O.C.; Raffrenato, E.; Muchenje, V.; Musarurwa, H.T.; Mapiye, C. Varietal differences in nutrient, amino acid and mineral composition and in vitro rumen digestibility of grape (Vitis vinifera) pomace from the Cape Winelands vineyards in South Africa and impact of preservation techniques. Industrial Crops and Products 2018, 118, 30-37, https://doi.org/10.1016/j.indcrop.2018.03.026. 
31. Sousa, E.C.; Uchôa-Thomaz, A.M.A.; Carioca, J.O.B.; Morais, S.M.d.; Lima, A.d.; Martins, C.G.; Alexandrino, C.D.; Ferreira, P.A.T.; Rodrigues, A.L.M.; Rodrigues, S.P. Chemical composition and bioactive compounds of grape pomace (Vitis vinifera L.), Benitaka variety, grown in the semiarid region of Northeast Brazil. Food Science and Technology 2014, 34, 135-142, https://doi.org/10.1590/S010120612014000100020.

32. Zeghad, N.; Ahmed, E.; Belkhiri, A.; Vander Heyden, Y.; Demeyer, K. Antioxidant activity of Vitis vinifera, Punica granatum, Citrus aurantium and Opuntia ficus indica fruits cultivated in Algeria. Heliyon 2019, 5 , e01575, https://doi.org/10.1016/j.heliyon.2019.e01575.

33. Yilmaz, Y.; Göksel, Z.; Erdoğan, S.S.; Öztürk, A.; Atak, A.; Özer, C. Antioxidant Activity and Phenolic Content of Seed, Skin and Pulp Parts of 22 Grape (Vitis vinifera L.) Cultivars (4 Common and 18 Registered or Candidate for Registration). J. Food Process. Preserv. 2015, 39, 1682-1691, https://doi.org/10.1111/jfpp.12399.

34. Pavić, V.; Kujundžić, T.; Kopić, M.; Jukić, V.; Braun, U.; Schwander, F.; Drenjančević, M. Effects of Defoliation on Phenolic Concentrations, Antioxidant and Antibacterial Activity of Grape Skin Extracts of the Varieties Blaufränkisch and Merlot (Vitis vinifera L.). Molecules 2019, 24, https://doi.org/10.3390/molecules24132444.

35. Liu, Q.; Tang, G.-Y.; Zhao, C.-N.; Feng, X.-L.; Xu, X.-Y.; Cao, S.-Y.; Meng, X.; Li, S.; Gan, R.-Y.; Li, H.B. Comparison of antioxidant activities of different grape varieties. Molecules 2018, 23, 2432, https://doi.org/10.3390/molecules23102432.

36. Moldovan, M.L.; Carpa, R.; Fizeșan, I.; Vlase, L.; Bogdan, C.; Iurian, S.M.; Benedec, D.; Pop, A. Phytochemical Profile and Biological Activities of Tendrils and Leaves Extracts from a Variety of Vitis vinifera L. Antioxidants 2020, 9, https://doi.org/10.3390/antiox9050373.

37. Balea, Ş.S.; Pârvu, A.E.; Pârvu, M.; Vlase, L.; Dehelean, C.A.; Pop, T.I. Antioxidant, Anti-Inflammatory and Antiproliferative Effects of the Vitis vinifera L. var. Fetească Neagră and Pinot Noir Pomace Extracts. Front. Pharmacol. 2020, 11, 990, https://doi.org/10.3389/fphar.2020.00990.

38. Sangiovanni, E.; Di Lorenzo, C.; Piazza, S.; Manzoni, Y.; Brunelli, C.; Fumagalli, M.; Magnavacca, A.; Martinelli, G.; Colombo, F.; Casiraghi, A.; Melzi, G.; Marabini, L.; Restani, P.; Dell'Agli, M. Vitis vinifera L. Leaf Extract Inhibits In Vitro Mediators of Inflammation and Oxidative Stress Involved in InflammatoryBased Skin Diseases. Antioxidants 2019, 8, https://doi.org/10.3390/antiox8050134.

39. Simonetti, G.; Palocci, C.; Valletta, A.; Kolesova, O.; Chronopoulou, L.; Donati, L.; Di Nitto, A.; Brasili, E.; Tomai, P.; Gentili, A.; Pasqua, G. Anti-Candida Biofilm Activity of Pterostilbene or Crude Extract from NonFermented Grape Pomace Entrapped in Biopolymeric Nanoparticles. Molecules 2019, 24, https://doi.org/10.3390/molecules24112070.

40. Simonetti, G.; Brasili, E.; Pasqua, G. Antifungal Activity of Phenolic and Polyphenolic Compounds from Different Matrices of Vitis vinifera L. against Human Pathogens. Molecules 2020, 25, https://doi.org/10.3390/molecules25163748.

41. Fraternale, D.; Ricci, D.; Verardo, G.; Gorassini, A.; Stocchi, V.; Sestili, P. Activity of Vitis vinifera tendrils extract against phytopathogenic fungi. Nat. Prod. Commun. 2015, 10, https://doi.org/10.1177/1934578X1501000661.

42. Manipal, S.; Fathima, L.; Hussain T, S.; R, V. Efficacy of antibacterial and antifungal action on four medicinal plants extract the A.arabica, T.chebula, A.indica, and V.vinifera against Streptococcus mutans and Candida albicans -An in-vitro study. Int J Res Pharm Sci 2019, 10, 3121-3126, https://doi.org//10.26452/ijrps.v10i4.1608.

43. Simonetti, G.; Santamaria, A.R.; D’Auria, F.D.; Mulinacci, N.; Innocenti, M.; Cecchini, F.; Pericolini, E.; Gabrielli, E.; Panella, S.; Antonacci, D.; et al. Seed Extracts Obtained from Wine and Table Cultivars. BioMed Research International 2014, 2014, 127021, https://doi.org/10.1155/2014/127021.

44. Simonetti, G.; D'Auria, F.D.; Mulinacci, N.; Innocenti, M.; Antonacci, D.; Angiolella, L.; Santamaria, A.R.; Valletta, A.; Donati, L.; Pasqua, G. Anti-Dermatophyte and Anti-Malassezia Activity of Extracts Rich in Polymeric Flavan-3-ols Obtained from Vitis vinifera Seeds. Phytother. Res. 2017, 31, 124-131, https://doi.org/10.1002/ptr.5739.

45. Houillé, B.; Papon, N.; Boudesocque, L.; Bourdeaud, E.; Besseau, S.; Courdavault, V.; Enguehard-Gueiffier, C.; Delanoue, G.; Guérin, L.; Bouchara, J.-P.; Clastre, M.; Giglioli-Guivarc'h, N.; Guillard, J.; Lanoue, A. Antifungal Activity of Resveratrol Derivatives against Candida Species. J. Nat. Prod. 2014, 77, 1658-1662, https://doi.org/10.1021/np5002576. 
46. Leal, C.; Santos, R.A.; Pinto, R.; Queiroz, M.; Rodrigues, M.; José Saavedra, M.; Barros, A.; Gouvinhas, I. Recovery of bioactive compounds from white grape (Vitis vinifera L.) stems as potential antimicrobial agents for human health. Saudi J. Biol. Sci. 2020, 27, 1009-1015, https://doi.org/10.1016/j.sjbs.2020.02.013.

47. Ostberg-Potthoff, J.J.; Berger, K.; Richling, E.; Winterhalter, P. Activity-Guided Fractionation of Red Fruit Extracts for the Identification of Compounds Influencing Glucose Metabolism. Nutrients 2019, 11, https://doi.org/10.3390/nu11051166.

48. Doshi, P.; Adsule, P.; Banerjee, K.; Oulkar, D. Phenolic compounds, antioxidant activity and insulinotropic effect of extracts prepared from grape ( Vitis vinifera L ) byproducts. J. Food Sci. Technol. 2015, 52, 181190, https://doi.org/10.1007/s13197-013-0991-1.

49. Gharib, A.; Faezizadeh, Z.; Godarzee, M. Treatment of diabetes in the mouse model by delphinidin and cyanidin hydrochloride in free and liposomal forms. Planta Med. 2013, 79, 1599-1604, https://doi.org/10.1055/s-0033-1350908.

50. Soares de Moura, R.; da Costa, G.F.; Moreira, A.S.B.; Queiroz, E.F.; Moreira, D.D.C.; Garcia-Souza, E.P.; Resende, Â.C.; Moura, A.S.; Teixeira, M.T. Vitis vinifera L. grape skin extract activates the insulin-signalling cascade and reduces hyperglycaemia in alloxan-induced diabetic mice. J. Pharm. Pharmacol. 2012, 64, 268276, https://doi.org/10.1111/j.2042-7158.2011.01395.x.

51. da Costa, G.F.; Ognibene, D.T.; da Costa, C.A.; Teixeira, M.T.; Cordeiro, V.d.S.C.; de Bem, G.F.; Moura, A.S.; de Castro Resende, A.; de Moura, R.S. Vitis vinifera L. Grape Skin Extract Prevents Development of Hypertension and Altered Lipid Profile in Spontaneously Hypertensive Rats: Role of Oxidative Stress. Preventive nutrition and food science 2020, 25, 25, https://doi.org/10.3746/pnf.2020.25.1.25.

52. Godse, S.; Mohan, M.; Kasture, V.; Kasture, S. Effect of myricetin on blood pressure and metabolic alterations in fructose hypertensive rats. Pharm. Biol. 2010, 48, 494-498, https://doi.org/10.3109/13880200903188526.

53. Borde, P.; Mohan, M.; Kasture, S. Effect of myricetin on deoxycorticosterone acetate (DOCA)-salthypertensive rats. Nat. Prod. Res. 2011, 25, 1549-1559, https://doi.org/10.1080/14786410903335190.

54. Santos, I.B.; de Bem, G.F.; Cordeiro, V.S.C.; da Costa, C.A.; de Carvalho, L.C.R.M.; da Rocha, A.P.M.; da Costa, G.F.; Ognibene, D.T.; de Moura, R.S.; Resende, A.C. Supplementation with Vitis vinifera L. skin extract improves insulin resistance and prevents hepatic lipid accumulation and steatosis in high-fat diet-fed mice. Nutr. Res. 2017, 43, 69-81, https://doi.org/10.1016/j.nutres.2017.05.007.

55. da Costa, G.F.; Santos, I.B.; de Bem, G.F.; Cordeiro, V.S.C.; da Costa, C.A.; de Carvalho, L.C.R.M.; Ognibene, D.T.; Resende, A.C.; de Moura, R.S. The Beneficial Effect of Anthocyanidin-Rich Vitis vinifera L. Grape Skin Extract on Metabolic Changes Induced by High-Fat Diet in Mice Involves Antiinflammatory and Antioxidant Actions. Phytother. Res. 2017, 31, 1621-1632, https://doi.org/10.1002/ptr.5898.

56. Fan, M.; Choi, Y.-J.; Tang, Y.; Bae, S.M.; Yang, H.P.; Kim, E.-K. Efficacy and Mechanism of Polymerized Anthocyanin from Grape-Skin Extract on High-Fat-Diet-Induced Nonalcoholic Fatty Liver Disease. Nutrients 2019, 11, https://doi.org/10.3390/nu11112586.

57. Giribabu, N.; Kumar, K.E.; Rekha, S.S.; Muniandy, S.; Salleh, N. Vitis vinifera (Muscat Variety) Seed Ethanolic Extract Preserves Activity Levels of Enzymes and Histology of the Liver in Adult Male Rats with Diabetes. Evid. Based Complement. Alternat. Med. 2015, 2015, 542026, https://doi.org/10.1155/2015/542026.

58. Dai, J.; Wang, G.; Li, W.; Zhang, L.; Yang, J.; Zhao, X.; Chen, X.; Xu, Y.; Li, K. High-Throughput Screening for Anti-Influenza A Virus Drugs and Study of the Mechanism of Procyanidin on Influenza A Virus-Induced Autophagy. J. Biomol. Screen. 2012, 17, 605-617, https://doi.org/10.1177/1087057111435236.

59. Lin, S.-C.; Ho, C.-T.; Chuo, W.-H.; Li, S.; Wang, T.T.; Lin, C.-C. Effective inhibition of MERS-CoV infection by resveratrol. BMC Infect. Dis. 2017, 17, 144, https://doi.org/10.1186/s12879-017-2253-8.

60. Kaur, A.; Gupta, V.; Christopher, A.F.; Malik, M.A.; Bansal, P. Nutraceuticals in prevention of cataract - An evidence based approach. Saudi Journal of Ophthalmology 2017, 31, 30-37, https://doi.org/10.1016/j.sjopt.2016.12.001.

61. Higashi, Y.; Higashi, K.; Mori, A.; Sakamoto, K.; Ishii, K.; Nakahara, T. Anti-cataract Effect of Resveratrol in High-Glucose-Treated Streptozotocin-Induced Diabetic Rats. Biol. Pharm. Bull. 2018, 41, 1586-1592, https://doi.org/10.1248/bpb.b18-00328.

62. Kwak, S.C.; Cheon, Y.-H.; Lee, C.H.; Jun, H.Y.; Yoon, K.-H.; Lee, M.S.; Kim, J.-Y. Grape Seed Proanthocyanidin Extract Prevents Bone Loss via Regulation of Osteoclast Differentiation, Apoptosis, and Proliferation. Nutrients 2020, 12, https://doi.org/10.3390/nu12103164. 
63. Sei-ichi, K.; Toda, K.; Matsumoto, K.; Ishihara, C.; Nonobe, S.; Matsunaga, C.; Gomi, Y.K.; Senga, S.; Kawaguchi, K.; Yamamoto, A.; Suwannachot, J.; Noda, R.; Kobayashi, S.; Hamauzu, Y.; Makabe, H.; Fujii, H. Isolation and characterization of a novel oligomeric proanthocyanidin with significant anticancer activities from grape stems ( Vitis vinifera ). Sci. Rep. 2019, 9, 12046, https://doi.org/10.1038/s41598-019-48603-5.

64. Grace Nirmala, J.; Evangeline Celsia, S.; Swaminathan, A.; Narendhirakannan, R.T.; Chatterjee, S. Cytotoxicity and apoptotic cell death induced by Vitis vinifera peel and seed extracts in A431 skin cancer cells. Cytotechnology 2018, 70, 537-554, https://doi.org/10.1007/s10616-017-0125-0.

65. Decean, H.; Fischer-Fodor, E.; Tatomir, C.; Perde-Schrepler, M.; Somfelean, L.; Burz, C.; Hodor, T.; Orasan, R.; Virag, P. Vitis vinifera seeds extract for the modulation of cytosolic factors BAX- $\alpha$ and NF-kB involved in UVB-induced oxidative stress and apoptosis of human skin cells. Clujul Medical 2016, 89, 72, https://doi.org/10.15386/cjmed-508.

66. Leone, A.; Longo, C.; Gerardi, C.; Trosko, J.E. Pro-Apoptotic Effect of Grape Seed Extract on MCF-7 Involves Transient Increase of Gap Junction Intercellular Communication and Cx43 Up-Regulation: A Mechanism of Chemoprevention. Int. J. Mol. Sci. 2019, 20, https://doi.org/10.3390/ijms20133244.

67. Wahner-Roedler, D.L.; Bauer, B.A.; Loehrer, L.L.; Cha, S.S.; Hoskin, T.L.; Olson, J.E. The Effect of Grape Seed Extract on Estrogen Levels of Postmenopausal Women: A Pilot Study. J. Diet. Suppl. 2014, 11, 184197, https://doi.org/10.3109/19390211.2013.859220.

68. Giovannelli, L.; Innocenti, M.; Santamaria, A.R.; Bigagli, E.; Pasqua, G.; Mulinacci, N. Antitumoural activity of viniferin-enriched extracts from Vitis vinifera L. cell cultures. Nat. Prod. Res. 2014, 28, 2006-2016, https://doi.org/10.1080/14786419.2014.924935.

69. Aja, I.; Ruiz-Larrea, M.B.; Courtois, A.; Krisa, S.; Richard, T.; Ruiz-Sanz, J.-I. Screening of Natural Stilbene Oligomers from Vitis vinifera for Anticancer Activity on Human Hepatocellular Carcinoma Cells. Antioxidants 2020, 9, https://doi.org/10.3390/antiox9060469.

70. Rapaka, D.; Bitra, V.R.; Vishala, T.C.; Akula, A. Vitis vinifera acts as anti-Alzheimer's agent by modulating biochemical parameters implicated in cognition and memory. J. Ayurveda Integr. Med. 2019, 10, 241-247, https://doi.org/10.1016/j.jaim.2017.06.013.

71. Loureiro, J.A.; Andrade, S.; Duarte, A.; Neves, A.R.; Queiroz, J.F.; Nunes, C.; Sevin, E.; Fenart, L.; Gosselet, F.; Coelho, M.A.N.; Pereira, M.C. Resveratrol and Grape Extract-loaded Solid Lipid Nanoparticles for the Treatment of Alzheimer's Disease. Molecules 2017, 22, https://doi.org/10.3390/molecules22020277.

72. Ma, L.; Xiao, H.; Wen, J.; Liu, Z.; He, Y.; Yuan, F. Possible mechanism of Vitis vinifera L. flavones on neurotransmitters, synaptic transmission and related learning and memory in Alzheimer model rats. Lipids Health Dis. 2018, 17, 152, https://doi.org/10.1186/s12944-018-0708-6.

73. Nelson, K.; Lyles, J.T.; Li, T.; Saitta, A.; Addie-Noye, E.; Tyler, P.; Quave, C.L. Anti-Acne Activity of Italian Medicinal Plants Used for Skin Infection. Front. Pharmacol. 2016, 7, 425, https://doi.org/10.3389/fphar.2016.00425.

74. Cronin, H.; Draelos, Z.D. Original Contribution: Top 10 botanical ingredients in 2010 anti-aging creams. $J$. Cosmet. Dermatol. 2010, 9, 218-225, https://doi.org/10.1111/j.1473-2165.2010.00516.x.

75. Sharif, A.; Akhtar, N.; Khan, M.S.; Menaa, A.; Menaa, B.; Khan, B.A.; Menaa, F. Formulation and evaluation on human skin of a water-in-oil emulsion containing Muscat hamburg black grape seed extract. Int. J. Cosmetic Sci. 2015, 37, 253-258, https://doi.org/10.1111/ics.12184.

76. Boo, Y.C. Human Skin Lightening Efficacy of Resveratrol and Its Analogs: From in Vitro Studies to Cosmetic Applications. Antioxidants 2019, 8, https://doi.org/10.3390/antiox8090332.

77. Lin, Y.-S.; Chen, H.-J.; Huang, J.-P.; Lee, P.-C.; Tsai, C.-R.; Hsu, T.-F.; Huang, W.-Y. Kinetics of tyrosinase inhibitory activity using Vitis vinifera leaf extracts. BioMed Research International 2017, 2017, 5232680, https://doi.org/10.1155/2017/5232680.

78. Shanmuganayagam, D.; Beahm, M.R.; Kuhns, M.A.; Krueger, C.G.; Reed, J.D.; Folts, J.D. Differential Effects of Grape (Vitis vinifera) Skin Polyphenolics on Human Platelet Aggregation and Low-Density Lipoprotein Oxidation. J. Agric. Food Chem. 2012, 60, 5787-5794, https://doi.org/10.1021/jf203487g.

79. Bijak, M.; Sut, A.; Kosiorek, A.; Saluk-Bijak, J.; Golanski, J. Dual Anticoagulant/Antiplatelet Activity of Polyphenolic Grape Seeds Extract. Nutrients 2019, 11, https://doi.org/10.3390/nu11010093.

80. Shivananda Nayak, B.; Dan Ramdath, D.; Marshall, J.R.; Isitor, G.; Xue, S.; Shi, J. Wound-healing Properties of the Oils of Vitis vinifera and Vaccinium macrocarpon. Phytother. Res. 2011, 25, 1201-1208, https://doi.org/10.1002/ptr.3363. 
81. Nayak, B.S.; Ramdath, D.D.; Marshall, J.R.; Isitor, G.N.; Eversley, M.; Xue, S.; Shi, J. Wound-healing activity of the skin of the common grape (Vitis Vinifera) variant, cabernet sauvignon. Phytother. Res. 2010, 24, 1151-1157, https://doi.org/10.1002/ptr.2999.

82. Margină, D.; Olaru, O.T.; Ilie, M.; Grădinaru, D.; Guțu, C.; Voicu, S.; Dinischiotu, A.; Spandidos, D.A.; Tsatsakis, A.M. Assessment of the potential health benefits of certain total extracts from Vitis vinifera, Aesculus hyppocastanum and Curcuma longa. Exp. Ther. Med. 2015, 10, 1681-1688, https://doi.org/10.3892/etm.2015.2724.

83. Fernandes, F.; Ramalhosa, E.; Pires, P.; Verdial, J.; Valentão, P.; Andrade, P.; Bento, A.; Pereira, J.A. Vitis vinifera leaves towards bioactivity. Industrial Crops and Products 2013, 43, 434-440, https://doi.org/10.1016/j.indcrop.2012.07.031.

84. Gleńsk, M.; Hurst, W.J.; Glinski, V.B.; Bednarski, M.; Gliński, J.A. Isolation of 1-(3',4'-Dihydroxyphenyl)3-(2",4",6"-trihydroxyphenyl)-propan-2-ol from Grape Seed Extract and Evaluation of its Antioxidant and Antispasmodic Potential. Molecules 2019, 24, https://doi.org/10.3390/molecules24132466.

85. Wang, Y.; Wang, Y.; Shen, W.; Wang, Y.; Cao, Y.; Nuerbulati, N.; Chen, W.; Lu, G.; Xiao, W.; Qi, R. Grape seed polyphenols ameliorated dextran sulfate sodium-induced colitis via suppression of inflammation and apoptosis. Pharmacology 2020, 105, 9-18, https://doi.org/10.1159/000501897.

86. Jin, H.Y.; Cha, Y.S.; Baek, H.S.; Park, T.S. Neuroprotective effects of Vitis vinifera extract on prediabetic mice induced by a high-fat diet. Korean J. Intern. Med. 2013, 28, 579-586, https://doi.org/10.3904/kjim.2013.28.5.579.

87. Micheli, L.; Mattoli, L.; Maidecchi, A.; Pacini, A.; Ghelardini, C.; Di Cesare Mannelli, L. Effect of Vitis vinifera hydroalcoholic extract against oxaliplatin neurotoxicity: in vitro and in vivo evidence. Sci. Rep. 2018, 8, 14364, https://doi.org/10.1038/s41598-018-32691-w.

88. Ismail, A.F.M.; Moawed, F.S.M.; Mohamed, M.A. Protective mechanism of grape seed oil on carbon tetrachloride-induced brain damage in $\gamma$-irradiated rats. J. Photochem. Photobiol. B: Biol. 2015, 153, 317 323, https://doi.org/10.1016/j.jphotobiol.2015.10.005.

89. Lakshmi, B.V.S.; Sudhakar, M.; Anisha, M. Neuroprotective role of hydroalcoholic extract of Vitis vinifera against aluminium-induced oxidative stress in rat brain. Neurotoxicology 2014, 41, 73-79, https://doi.org/10.1016/j.neuro.2014.01.003.

90. Balea, Ş.S.; Pârvu, A.E.; Pop, N.; Marín, F.Z.; Pârvu, M. Polyphenolic Compounds, Antioxidant, and Cardioprotective Effects of Pomace Extracts from Fetească Neagră Cultivar. Oxid. Med. Cell. Longev. 2018, 2018, 8194721, https://doi.org/10.1155/2018/8194721.

91. Tenore, G.C.; Manfra, M.; Stiuso, P.; Coppola, L.; Russo, M.; Gomez Monterrey, I.M.; Campiglia, P. Antioxidant Profile and in Vitro Cardiac Radical-Scavenging versus Pro-oxidant Effects of Commercial Red Grape Juices (Vitis vinifera L. cv. Aglianico N.). J. Agric. Food Chem. 2012, 60, 9680-9687, https://doi.org/10.1021/jf301647d.

92. Sergazy, S.; Shulgau, Z.; Fedotovskikh, G.; Chulenbayeva, L.; Nurgozhina, A.; Nurgaziyev, M.; Krivyh, E.; Kamyshanskiy, Y.; Kushugulova, A.; Gulyayev, A.; Aljofan, M. Cardioprotective effect of grape polyphenol extract against doxorubicin induced cardiotoxicity. Sci. Rep. 2020, 10, 14720, https://doi.org/10.1038/s41598-020-71827-9.

93. Abdelsalam, H.M.; Samak, M.A.; Alsemeh, A.E. Synergistic therapeutic effects of Vitis vinifera extract and Silymarin on experimentally induced cardiorenal injury: The pertinent role of Nrf2. Biomedicine \& Pharmacotherapy 2019, 110, 37-46, https://doi.org/10.1016/j.biopha.2018.11.053.

94. Park, H.-J.; Jung, U.J.; Lee, M.-K.; Cho, S.-J.; Jung, H.-K.; Hong, J.H.; Park, Y.B.; Kim, S.R.; Shim, S.; Jung, J.; Choi, M.-S. Modulation of lipid metabolism by polyphenol-rich grape skin extract improves liver steatosis and adiposity in high fat fed mice. Mol. Nutr. Food Res. 2013, 57, 360-364, https://doi.org/10.1002/mnfr.201200447.

95. Dogan, A.; Celik, I. Hepatoprotective and antioxidant activities of grapeseeds against ethanol-induced oxidative stress in rats. Br. J. Nutr. 2012, 107, 45-51, https://doi.org/10.1017/S0007114511002650.

96. Madi Almajwal, A.; Farouk Elsadek, M. Lipid-lowering and hepatoprotective effects of Vitis vinifera dried seeds on paracetamol-induced hepatotoxicity in rats. Nutr. Res. Pract. 2015, 9, 37-42, https://doi.org/10.4162/nrp.2015.9.1.37.

97. Puglisi, R.; Severgnini, A.; Tava, A.; Montedoro, M. In vitro assessment of the antioxidant properties of aqueous byproduct extracts of Vitis vinifera. Food Technol. Biotechnol. 2019, 57, 119-125, https://doi.org/10.17113/ftb.57.01.19.5879. 
98. De Sales, N.F.F.; Silva da Costa, L.; Carneiro, T.I.A.; Minuzzo, D.A.; Oliveira, F.L.; Cabral, L.M.C.; Torres, A.G.; El-Bacha, T. Anthocyanin-Rich Grape Pomace Extract (Vitis vinifera L.) from Wine Industry Affects Mitochondrial Bioenergetics and Glucose Metabolism in Human Hepatocarcinoma HepG2 Cells. Molecules 2018, 23, https://doi.org/10.3390/molecules23030611.

99. Liang, Z.; Cheng, L.; Zhong, G.-Y.; Liu, R.H. Antioxidant and Antiproliferative Activities of Twenty-Four Vitis vinifera Grapes. PLoS One 2014, 9, e105146, https://doi.org/10.1371/journal.pone.0105146.

100.Lluís, L.; Muñoz, M.; Rosa Nogués, M.; Sánchez-Martos, V.; Romeu, M.; Giralt, M.; Valls, J.; Solà, R. Toxicology evaluation of a procyanidin-rich extract from grape skins and seeds. Food Chem. Toxicol. 2011, 49, 1450-1454, https://doi.org/10.1016/j.fct.2011.03.042. 